Nevada

Environmental

Restoration

Project

\title{
Addendum to the Closure Report for Corrective Action Unit 326: \\ Areas 6 and 27 Release Sites, \\ Nevada Test Site, Nevada
}

Controlled Copy No::

Revision No.: 0

May 2009

Approved for public release; further dissemination unlimited.

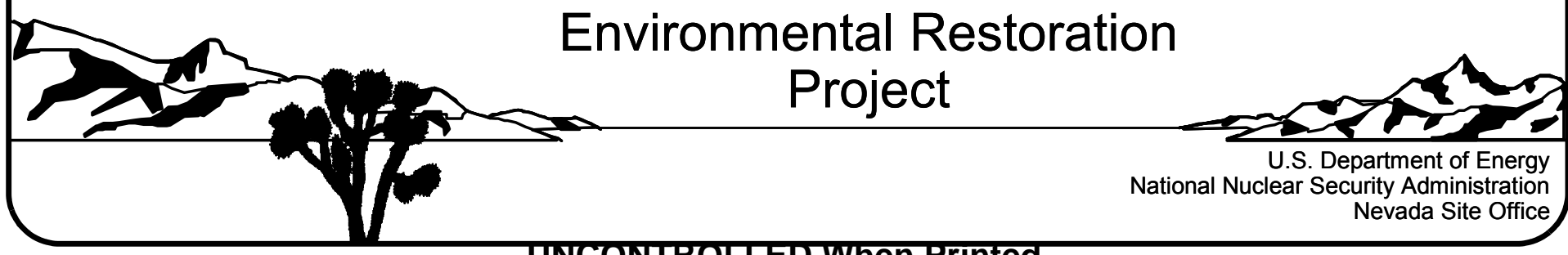


Available for public sale, in paper, from:

U.S. Department of Commerce

National Technical Information Service

5285 Port Royal Road

Springfield, VA 22161

Phone: 800.553 .6847

Fax: 703.605.6900

Email: orders@ntis.gov

Online ordering: http://www.ntis.gov/ordering.htm

Available electronically at $\underline{h t p: / / w w w . o s t i . g o v / b r i d g e ~}$

Available for a processing fee to U.S. Department of Energy and its contractors, in paper, from:

U.S. Department of Energy

Office of Scientific and Technical Information

P.O. Box 62

Oak Ridge, TN 37831-0062

Phone: 865.576 .8401

Fax: 865.576.5728

Email: reports@adonis.osti.gov

Reference herein to any specific commercial product, process, or service by trade name, trademark, manufacturer, or otherwise, does not necessarily constitute or imply its endorsement, recommendation, or favoring by the United States Government or any agency thereof or its contractors or subcontractors. 


\title{
ADDENDUM TO THE CLOSURE REPORT FOR CORRECTIVE ACTION UNIT 326: AREAS 6 AND 27 RELEASE SITES, NEVADA TEST SITE, NEVADA
}

\author{
U.S. Department of Energy \\ National Nuclear Security Administration \\ Nevada Site Office \\ Las Vegas, Nevada
}

Controlled Copy No.:

Revision No.: 0

May 2009

Approved for public release; further dissemination unlimited.

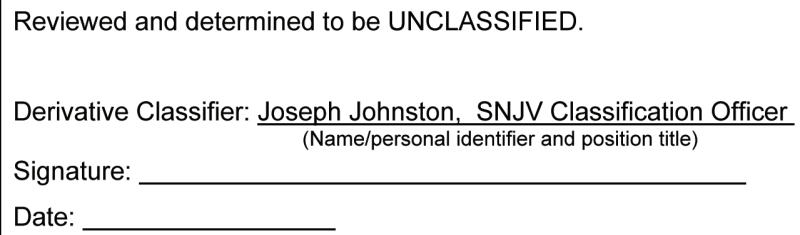




\section{Addendum to the Closure Report for Removal of the Use Restriction}

This document constitutes an addendum to the Closure Report for Corrective Action Unit 326: Areas 6 and 27 Release Sites, Nevada Test Site, Nevada (Revision 1), December 2002 as described in the document Supplemental Investigation Report for FFACO Use Restrictions, Nevada Test Site, Nevada (SIR) dated November 2008. The SIR document was approved by NDEP on December 5, 2008. The approval of the SIR document constituted approval of each of the recommended UR removals. In conformance with the SIR document, this addendum consists of:

- This page that refers the reader to the SIR document for additional information

- The cover, title, and signature pages of the SIR document

- The NDEP approval letter

- The corresponding section of the SIR document

This addendum provides the documentation justifying the cancellation of the UR for CAS 06-25-01, CP-1 Heating Oil Release. This UR was established as part of a Federal Facility Agreement and Consent Order (FFACO) corrective action and is based on the presence of contaminants at concentrations greater than the action levels established at the time of the initial investigation (FFACO, 1996).

Since this UR was established, practices and procedures relating to the implementation of risk-based corrective actions (RBCA) have changed. Therefore, this UR was reevaluated against the current RBCA criteria as defined in the Industrial Sites Project Establishment of Final Action Levels (NNSA/NSO, 2006). This re-evaluation consisted of comparing the original data (used to define the need for the UR) to risk-based final action levels (FALs) developed using the current Industrial Sites RBCA process.

The re-evaluation resulted in a recommendation to remove the UR because contamination is not present at the site above the risk-based FALs. Requirements for inspecting and maintaining this UR will be canceled, and the postings and signage at this site will be removed. Fencing and posting may be present at this site that are unrelated to the FFACO UR such as for radiological control purposes as required by the NV/YMP Radiological Control Manual (NNSA/NSO, 2004). This modification will not affect or modify any non-FFACO requirements for fencing, posting, or monitoring at this site.

\section{References}

FFACO, see Federal Facility Agreement and Consent Order.

Federal Facility Agreement and Consent Order. 1996 (as amended). Agreed to by the State of Nevada, U.S. Department of Energy, and U.S. Department of Defense.

NNSA/NSO, see U.S. Department of Energy, National Nuclear Security Administration Nevada Site Office. 
NNSA/NV, see U.S. Department of Energy, National Nuclear Security Administration Nevada Operations Office.

U.S. Department of Energy, National Nuclear Security Administration Nevada Operations Office. 2002. Closure Report for Corrective Action Unit 326: Areas 6 and 27 Release Sites, Nevada Test Site, Nevada, Rev. 1, DOE/NV--859-Rev 1. December. Las Vegas, NV.

U.S. Department of Energy, National Nuclear Security Administration Nevada Site Office. 2004. NV/YMP Radiological Control Manual, DOE/NV/11718--079, Rev. 5. Prepared by Bechtel Nevada. Las Vegas, NV.

U.S. Department of Energy, National Nuclear Security Administration Nevada Site Office. 2006. Industrial Sites Project Establishment of Final Action Levels, Rev. 0, DOE/NV--1107. Las Vegas, NV.

U.S. Department of Energy, National Nuclear Security Administration Nevada Site Office. 2008. Supplemental Investigation Plan for FFACO Use Restrictions, Nevada Test Site, Nevada, Rev. 0, DOE/NV--1256. Las Vegas, NV. 
Nevada

Environmental

Restoration

Project

Supplemental Investigation Report for

FFACO Use Restrictions

Nevada Test Site, Nevada

Controlled Copy No::

Revision No.: 0

November 2008

Approved for public release; further dissemination unlimited.

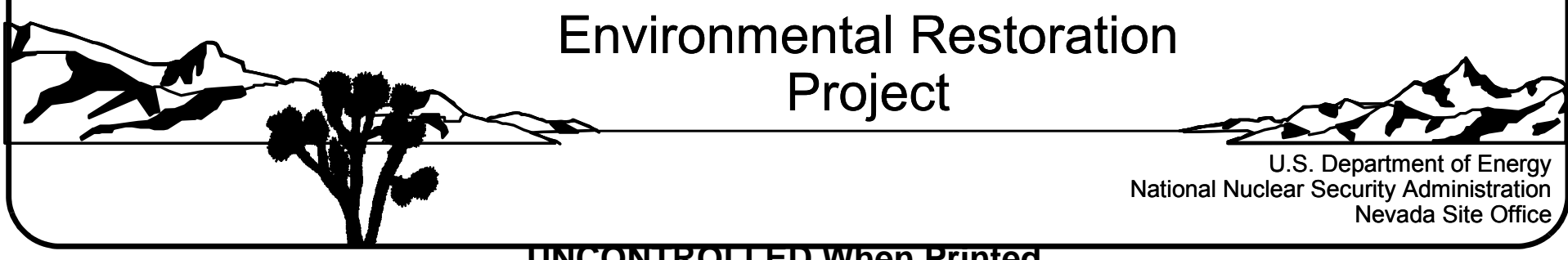




\section{SUPPLEMENTAL INVESTIGATION REPORT FOR FFACO USE RESTRICTIONS NEVADA TEST SITE, NEVADA}

U.S. Department of Energy

National Nuclear Security Administration

Nevada Site Office

Las Vegas, Nevada

Controlled Copy No.:

Revision No.: 0

Reviewed and determined to be UNCLASSIFIED.

This review does not constitute clearance for public release.

Derivative Classifier: Joseph Johnston, CO

Signature: /s/Joseph Johnston

Date: $11 / 24 / 20,08$

November 2008

Approved for public release; further dissemination unlimited. 


\section{SUPPLEMENTAL INVESTIGATION REPORT FOR FFACO USE RESTRICTIONS: NEVADA TEST SITE, NEVADA}

Approved by: /S/Kevin J. Cabble

Date: $11 / 12 / 2008$

Kevin J. Cabble

Federal Sub-Project Director

Industrial Sites Sub-Project

Approved by: /S/ Robert F. Boehlecke

Date: $11 / 12 / 2008$

Robert F. Boehlecke

Federal Project Director

Environmental Restoration Project 


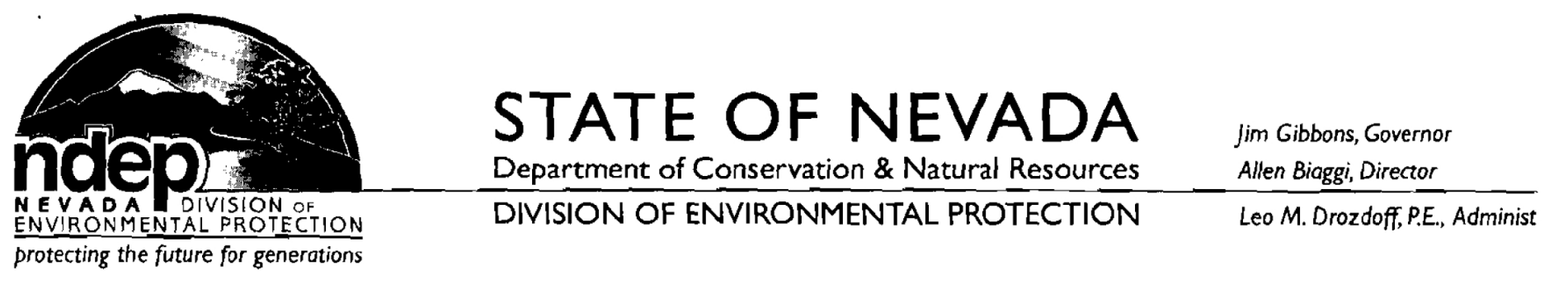

December 5, 2008

Robert F. Boehlecke

Federal Project Director

Environmental Restoration Project

National Nuclear Security Administration

Nevada Site Office

P. O. Box 98518

Las Vegas, NV 89193-8518

RE: Approval of Final Supplemental Investigation Report for FFACO Use Restrictions Nevada Test Site and Tonopah Test Range, Nevada, Revision 0, November 2008 Federal Facility Agreement and Consent Order

Dear Mr. Boehlecke:

The Nevada Division of Environmental Protection, Bureau of Federal Facilities (NDEP) staff has received and reviewed the submittal of the Final Supplemental Investigation Report for FFACO Use Restrictions, Nevada Test Site and Tonopah Test Range, Nevada, Revision 0 , November 2008. The report is hereby approved without comments pursuant to Subpart XII.8.a of the Federal Facility Agreement and Consent Order (FFACO).

Address any questions regarding this matter to either Ted Zaferatos at (702) 486-2850, ext. 234, Jeff MacDougall at (702) 486-2850, ext. 233, or me at (702) 486-2850, ext. 231.

Sincerely,

/s/Chris Andres for

T.H. Murphy

Chief

Bureau of Federal Facilities
ACTION

INFO

NSO/MGR

AMBCM

AMEM

AMNS

AMSO

AMSS

COR-RAI-

File Code 
Robert F. Boehlecke

Page 2

December 5, 2008

JJM $/ T Z$

cc: $\quad$ K. J. Cabble, ERP, NNSA/NSO, Las Vegas, NV

E.F. DiSanza, WMP, NNSA/NSO

FFACO Group, PSG, NNSA/NSO, Las Vegas, NV

Jeffrey Fraher, DTRAVCXT, Kirkland AFB, NM

W.R. Griffin, SNJV/DTRA, M/S 645, Mercury, NV

T.A. Thiele, NSTec, Las Vegas, NV

John Wong, Dennis Nicodemus, Kevin Campbell, NDEP Las Vegas, NV 


\subsection{CAU 326, CAS 06-25-01 - CP-1 Heating Oil Release}

\subsubsection{CAS Description}

Corrective Action Site 06-25-01 is located in Area 6 and consists of a surface and subsurface heating oil release at Building CP-1. The release was the result of a rupture that occurred in a pressurized underground pipe carrying diesel oil from an underground heating oil tank to a boiler in Building CP-1. The release occurred midway between these two features and appeared in the CP parking lot. The surface oil was collected and disposed of, but the subsurface oil was not. The heating oil tank, Tank 6-CP-1, was closed in place by removing its contents, cleaning the tank, and backfilling it with cement. The impacted soil around the tank was administratively closed in place with approval from NDEP. The CAS was subject to corrective actions that resulted in the implementation of a UR (NNSA/NV, 2001).

\subsubsection{Current Use Restriction Description}

A UR is in place at the site due to TPH contamination. The UR, as recorded in the FFACO, states the future use of land related to this CAU, as described by surveyed location, is restricted from DOE or U.S. Air Force activity that may alter or modify the containment control, as identified by the state and the $\mathrm{CR}$ or other $\mathrm{CAU}$ documentation, unless appropriate concurrence is obtained in advance.

Advance approval must be obtained from NNSA/NSO Industrial Sites before subsurface activities at these locations, including routine maintenance, repair, or other activities. A UR was implemented at three locations for this CAS: (1) around the original pipeline break in the Area $6 \mathrm{CP}$ bus parking lot, (2) at a segment of pipeline adjacent Building CP-1 extending east over a utility corridor, and (3) around an exposed broken pipeline located between the Area $6 \mathrm{CP}$ access road and the south edge of the bus parking lot. There are no monitoring requirements associated with the UR (NNSA/NV, 2002a).

\subsubsection{Basis for Current Use Restriction}

Samples were collected from CAS 06-25-01 and analyzed for TPH. The TPH concentrations exceeded the action level of $100 \mathrm{mg} / \mathrm{kg}$ in 9 of 31 samples; therefore, a UR was implemented. Table 4-1 contains analytical results for soil samples used to establish UR 06-25-01 (NNSA/NV, 2002a). 
Table 4-1

Sample Results for the Basis of UR 06-25-01

\begin{tabular}{|c|c|c|c|}
\hline \multirow{2}{*}{$\begin{array}{c}\text { Sample } \\
\text { Identification }\end{array}$} & \multirow[b]{2}{*}{ Location } & \multirow{2}{*}{$\begin{array}{l}\text { Depth } \\
\text { (ft bgs) }\end{array}$} & \multirow{2}{*}{$\begin{array}{c}\text { TPH (mg/kg) } \\
\text { Action Level } \\
100 \mathrm{mg} / \mathrm{kg}\end{array}$} \\
\hline & & & \\
\hline $062501-13$ & East pipeline segment & 2 & 1,500 \\
\hline $062501-22$ & East pipeline segment & 2 & 3,000 \\
\hline $062501-23$ & East pipeline segment & 2 & 220 \\
\hline 062501-24 & East pipeline segment & 2 & 1,200 \\
\hline $062501-25$ & East pipeline segment & 2 & 9,000 \\
\hline 326-B1-10 & Borehole Number B1 & 10 & 5,700 \\
\hline $326-B 1-45$ & Borehole Number B1 & 45 & 4,300 \\
\hline 326-B2-05 & Borehole Number B2 & 5 & 1,300 \\
\hline Pipeline 2 & Surface grab from break & 0 & 11,000 \\
\hline 062501-S4 & $3 \mathrm{ft}$ south of break & 2 & 4,300 \\
\hline
\end{tabular}

Note: Bold text indicates value exceeding the action level.

bgs $=$ Below ground surface

$\mathrm{ft}=$ Foot

$\mathrm{mg} / \mathrm{kg}=$ Milligrams per kilogram

$\mathrm{TPH}=$ Total petroleum hydrocarbons

\subsubsection{Basis for Use Restriction Modification}

Three new environmental samples were collected at CAS 06-25-01 according to the sampling plan (NNSA/NSO, 2008) and analyzed for VOCs and SVOCs in which the hazardous constituents of TPH are reported. Table 4-2 presents the VOC results that were detected above the MDCs. None of the SVOCs were detected above MDCs.

The analytical results were evaluated using the RBCA process (NNSA/NSO, 2006) in which the individual results of contaminants (detected above the MDCs) were compared to the FALs. None of the hazardous constituents of TPH were identified above their respective FALs; therefore, there are no COCs present at this site. 
Table 4-2

\section{Sample Results for VOCs Detected above Minimum}

Detectable Concentrations at UR 06-25-01

\begin{tabular}{|c|c|c|c|c|}
\hline \multirow{2}{*}{$\begin{array}{l}\text { Sample } \\
\text { Location }\end{array}$} & \multirow{2}{*}{$\begin{array}{l}\text { Sample } \\
\text { Number }\end{array}$} & \multirow{2}{*}{$\begin{array}{l}\text { Depth } \\
\text { (ft bgs) }\end{array}$} & \multicolumn{2}{|c|}{ Contaminants of Potential Concern (mg/kg) } \\
\hline & & & Methylene Chloride & Tetrachloroethylene \\
\hline \multicolumn{3}{|c|}{ Final Action Levels ${ }^{a}$} & 21 & 1.3 \\
\hline \multirow{3}{*}{ B03 } & 326B002 & $1.5-2.0$ & -- & 0.00199 \\
\hline & $326 \mathrm{~B} 003$ & $2.0-2.5$ & $0.00251(\mathrm{~J})$ & 0.0019 \\
\hline & 326B004 & $2.0-2.5$ & $0.00437(\mathrm{~J})$ & 0.00129 \\
\hline
\end{tabular}

aBased on U.S. Environmental Protection Agency, Regional Screening Levels for Chemical Contaminants at Superfund Sites (EPA, 2008a).

bgs $=$ Below ground surface

$\mathrm{ft}=$ Foot

$\mathrm{mg} / \mathrm{kg}=$ Milligrams per kilogram
$\mathrm{J}=$ Estimated value

-- = Not detected above minimum detectable concentrations.

\subsubsection{Recommended Modification}

Remove the FFACO UR, signage, and associated inspection and maintenance requirements from this site.

\subsection{CAU 339, CAS 12-19-01 - A12 Fleet Ops Steam Cleaning Efflu.}

\subsubsection{CAS Description}

Corrective Action Site 12-19-01 is located in the southeast portion of the Area 12 Camp at the former Area 12 Fleet Operations Building 12-16. The site consists of a surface discharge from a sand/oil interceptor that was in operation from sometime in 1965 to January 1993. The site served as a maintenance facility for light- and heavy-duty vehicles. The discharged effluent from steam cleaning activities at the site occurred approximately $340 \mathrm{ft}$ east of the facility, and resulted in concentrations of TPH that required the removal of approximately $80 \mathrm{yd}^{3}$ of contaminated soil, and the emplacement of a UR for the remaining TPH-impacted soil (DOE/NV, 1997a and c).

\subsubsection{Current Use Restriction Description}

A UR is in place at the site due to TPH contamination. As described in the FFACO, the UR states that the future use of land related to this CAU, as described by surveyed location, is restricted from 


\section{References}

DOE/NV, see U.S. Department of Energy, Nevada Operations Office.

EPA, see U.S. Environmental Protection Agency.

FFACO, see Federal Facility Agreement and Consent Order.

Federal Facility Agreement and Consent Order. 1996 (as amended February 2008). Agreed to by the State of Nevada; U.S. Department of Energy, Environmental Management; U.S. Department of Defense; and U.S. Department of Energy, Legacy Management.

NNSA/NSO, see U.S. Department of Energy, National Nuclear Security Administration Nevada Site Office.

NNSA/NV, see U.S. Department of Energy, National Nuclear Security Administration Nevada Operations Office.

U.S. Department of Energy, National Nuclear Security Administration Nevada Operations Office. 2001. Streamlined Approach for Environmental Restoration Plan for Corrective Action Unit 326: Areas 6 and 27 Release Sites, Nevada Test Site, Rev. 0, DOE/NV--751. September. Las Vegas, NV.

U.S. Department of Energy, National Nuclear Security Administration Nevada Operations Office. 2002a. Closure Report for Corrective Action Unit 326: Areas 6 and 27 Release Sites, Nevada Test Site, Nevada, Rev. 1, DOE/NV--859-Rev 1. December. Las Vegas, NV.

U.S. Department of Energy, National Nuclear Security Administration Nevada Site Office. 2004f. NV/YMP Radiological Control Manual, DOE/NV--11718-079, Rev. 5. Prepared by Bechtel Nevada. Las Vegas, NV.

U.S. Department of Energy, National Nuclear Security Administration Nevada Site Office. 2006. Industrial Sites Project Establishment of Final Action Levels, Rev. 0, DOE/NV--1107. Las Vegas, NV.

U.S. Department of Energy, National Nuclear Security Administration Nevada Site Office. 2008. Supplemental Investigation Plan for FFACO Use Restrictions, Nevada Test Site, Nevada, Rev. 0, DOE/NV--1256. Las Vegas, NV.

U.S. Department of Energy, Nevada Operations Office. 1997a. Closure Report for CAU 339: Area 12 Fleet Operations Steam Cleaning Discharge Area, Nevada Test Site, Rev. 0, DOE/NV/11718-167. December. Las Vegas, NV. 
U.S. Department of Energy, Nevada Operations Office. 1997c. Corrective Action Plan for CAU 339: Area 12 Fleet Operations Steam Cleaning Discharge Area, Nevada Test Site, Nevada, Rev. 0, DOE/NV/11718-106. May. Las Vegas, NV.

U.S. Environmental Protection Agency. 2008a. Regional Screening Levels for Chemical Contaminants at Superfund Sites. As accessed at http://epa-prgs.ornl.gov/chemicals/index.shtml on 27 July. Prepared by EPA Office of Superfund and Oak Ridge National Laboratory. 


\section{Library Distribution List}

\section{$\underline{\text { Copies }}$}

U.S. Department of Energy

1 (Uncontrolled, electronic copy)

National Nuclear Security Administration

Nevada Site Office

Technical Library

P.O. Box 98518, M/S 505

Las Vegas, NV 89193-8518

U.S. Department of Energy

1 (Uncontrolled, electronic copy)

Office of Scientific and Technical Information

P.O. Box 62

Oak Ridge, TN 37831-0062

Southern Nevada Public Reading Facility

2 (Uncontrolled, electronic copies)

c/o Nuclear Testing Archive

P.O. Box 98521, M/S 400

Las Vegas, NV 89193-8521

Manager, Northern Nevada FFACO

1 (Uncontrolled, electronic copy)

Public Reading Facility

c/o Nevada State Library \& Archives

100 N Stewart Street

Carson City, NV 89701-4285 